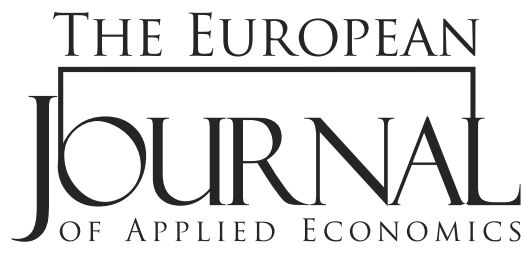

EJAE 2021, 18(1): $106-125$

ISSN 2406-2588

UDK: 159.9.072-057.875(497.11)

$005.342-057.875(497.11)$

DOI: $10.5937 /$ EJAE18-27707

Original paper/Originalni naučni rad

\title{
THE ENTERPRISE POTENTIAL, INDIVIDUAL ENTREPRENEURIAL ORIENTATION AND ENTREPRENEURIAL INTENTIONS OF STUDENTS IN SERBIA
}

\author{
Jelena Rajković* , Jasmina Poštin, Marko Konjikušić, Aleksandra Jagodić Rusić, Hadži Strahinja Stojković, \\ Milan Nikolić \\ University "Union Nikola Tesla", \\ Faculty of Engineering, \\ Belgrade, Serbia
}

\begin{abstract}
:
In this paper are given the findings of the research of the effects of five variables on the dimensions of the enterprise potential, individual entrepreneurial orientation, the Theory of Planned Behaviour (TPB) and dimension entrepreneurial intention, by students. The effects of the following variables are observed: Gender, One of my parents has a private business, The year in which the student is studying, Student success in learning and studying and The financial opportunities to start a new business. The respondents are studying at seven faculties in Serbia. The sample included 488 respondents. The most influential variable on the dimension entrepreneurial intentions is the financial opportunities to start a new business. Also, men have more pronounced entrepreneurial intentions. Success in studies positively influences entrepreneurial potentials and proactivity, while the possession of finance positively influences entrepreneurial intentions and risk readiness. In cases of successful studies and the possession of finance, women are more motivated, more determined, and have more pronounced entrepreneurial intentions (especially in the case of having financial resources). Although men may show a more preference to become entrepreneurs, women approach entrepreneurship more realistically and decisively.
\end{abstract}

\section{Article info:}

Received: July 29, 2020

Correction: September 7, 2020

Accepted: October 19, 2020

\section{Keywords:}

Enterprise potential, Individual entrepreneurial orientation,

Entrepreneurial intentions, Students,

Serbia.

JEL Classification:

L26, D23

\section{INTRODUCTION}

Entrepreneurship represents one of the leading aspects of socio-economic development (Coulibaly, Erbao, \& Mekongcho, 2018), and plays a key role in economic growth (Mahfud, Triyonoa, Sudiraa, \& Mulyani, 2020). More precisely, entrepreneurship contributes to job creation, increases productivity and competitiveness, encourages companies to innovate and act effectively (Mortan, Ripoll, Carvalho, \& Bernal, 2014), creates wealth and reduces unemployment (Paul, \& Shrivatava, 2016). 
Because of all this, it is not surprising that state institutions in many countries, at the highest levels, increasingly view entrepreneurship as an instrument for achieving economic growth and technological progress (Fellnhofer, \& Kraus, 2015). However, entrepreneurship is popular, not only from the perspective of state-level institutions, but also from the perspective of students as potential entrepreneurs, as well as academicians, as researchers in this field (Mwasalwiba, 2010).

Much of the research in the field of entrepreneurship is related to entrepreneurial intentions, their recognition, understanding and possibility to manage. Entrepreneurial intentions are important and deserve attention because, as proven, they confirm entrepreneurial behaviour (Koe, 2016; Sahinidis, Stavroulakis, Kossieri, \& Varelas, 2019). Delanoë-Gueguen and Fayolle (2018) point to the importance of the dynamics that connect entrepreneurial intentions and entrepreneurial actions. According to (Delanoë-Gueguen, \& Liñán, 2018), the greatest and lasting impact in this process (transition of entrepreneurial intentions in entrepreneurial actions) is the pursuit of providing the job security.

Entrepreneurial intentions represent a theoretical construct, which is very often used in order to explain the transition of an individual from ordinary thinking to concrete entrepreneurial action. Extensive literature in this area indicates that the importance of developing and nurturing initial entrepreneurial desires has been recognized, in order to enable the translation of these desires into immediate economic and social values (Donaldson, 2019). Similarly, Nowiński and Haddoud (2019) note that discovering everything that makes people engage in entrepreneurial activities occupies the special attention of researchers in the field of entrepreneurship and management, for over the last thirty years. Understanding these mechanisms is of great importance in forming appropriate programs to encourage and support entrepreneurial ventures. For example, research among students in Pakistan (Samo, \& Huda, 2019) has shown that support from governing structures and academic community has a strong, positive impact on entrepreneurial intentions, while industry impact is positive but not significant.

There are numerous influences on entrepreneurial intentions, as well as research examining these influences. What is important for this paper is that there are numerous research papers that deal with the influences of the gender of respondents on entrepreneurial intentions, for example (Santos et al., 2016; Huezo-Ponce, \& Saiz-Álvarez, 2020; Vamvaka, Stoforos, Palaskas, \& Botsaris, 2020; Nguyen, 2018), furthermore there are research papers that deal with influences of family background on entrepreneurial intentions (Jena, 2020; Herman, 2019; Palmer, Fasbender, Kraus, Birkner, \& Kailer, 2019; Sahinidis, Stavroulakis, Kossieri, \& Varelas, 2019; Hatak, Harms, \& Fink, 2015); research papers that deal with the influences of the age of the respondents on entrepreneurial intentions (Minola et al., 2016; Tsai et al., 2016; Nguyen, 2018) and research papers that deal with the influences of having the finances to start their own business on entrepreneurial intentions (Kim, Longest, \& Aldrich, 2013; Rodriguez, Tuggle, \& Hackett, 2009; Shinnar, \& Young, 2008; Sieger, \& Minola, 2017). The general impression is that similar research in Serbia has not yet been done to a sufficient extent.

The aim of this paper was to explore the impact of different variables on enterprise potential dimensions, individual entrepreneurial orientation dimensions, the Theory of Planned Behaviour (TPB) dimensions and entrepreneurial intention dimension (entrepreneurial dimensions). The research was carried out on students in Serbia. The effect of the following five variables is observed: Gender, One of my parents has a private business, The year in which the student is studying, Student success in learning and studying and The financial opportunities to start a new business. It should be noted that the students are similar in age, and therefore, in this part the focus is the year in which the student is studying, in order to see any changes in the initial and final years of study. It should be noted here that, in previous research, the year of study has not been sufficiently considered as an influential factor on entrepreneurial intentions. 
The possession of finance for opening one's own company variable is very important for the transition conditions in Serbia, where young people face serious financial constraints for starting their own business. Finally, the success in studies variable is, also, particularly interesting because it has not been widely considered so far in the context of entrepreneurial intentions.

The paper has a pronounced theoretical and practical contribution. The theoretical contribution and importance of the paper stem from the fact that, in many researches of various influences on entrepreneurial intentions, the influences of two variables have not been sufficiently observed so far: The year in which the student is studying and, especially, Student success in learning and studying. The practical contribution and importance of the paper is to consider the impact of the given five control variables on the entrepreneurial intentions of students in Serbia. Based on this acknowledgment, it will be possible to define certain, specific proposals, which may be useful to the relevant state institutions, which deal with the promotion of entrepreneurship in Serbia.

\section{THEORY}

\section{Enterprise Potential}

Enterprise potential presents the latent inclination of an individual to engage in entrepreneurship. The presence of such potentials does not imply the obligatory presence of a complete determination for a person to engage in entrepreneurship, or that this will happen, but only that such an individual possesses the characteristics and attitudes that favour the launch of an entrepreneurial venture. According to Athayde (2009) enterprise potential determination is a significant and frequently explored topic in the field of entrepreneurship. In this paper, enterprise potential is monitored and measured using the model established by Athayde (2009). This model contains the following constructs: leadership, creativity, achievement and personal control. A large number of references point to the importance of these dimensions for entrepreneurship.

\section{Individual Entrepreneurial Orientation}

According to Mueller and Thomas (2000), entrepreneurial orientation represents a group of individual characteristics, which have a connection with entrepreneurship. According to these authors, entrepreneurial orientation includes locus of control and innovativeness. This concept of was originally developed by Miller (1983) and basically has three constructs: risk taking, innovativeness and proactiveness. Observed at the individual level, entrepreneurial orientation is analogously transformed into individual entrepreneurial orientation (Robinson, \& Stubberud, 2014), which is important in studying the entrepreneurial intentions of individuals. A positive link between individual entrepreneurial orientation and entrepreneurial intentions is generally confirmed (Bolton, \& Lane, 2012; Koe, 2016; Muñoz-Bullón, Sánchez-Bueno, \& Vos-Saz, 2015; Reijonen, Hirvonen, Nagy, Laukkanen, \& Gabrielsson, 2015).

Risk taking is a feature that is more present in entrepreneurs than other people (Brandstätter, 2011; Caliendo, Fossen, \& Kritikos, 2014; Karabulut, 2016). Innovativeness is also more prominent in entrepreneurs than other people (Çolakoğlu \& Gözükara, 2016), and also has an impact on entrepreneurial intentions (Mueller, \& Thomas, 2000; Padilla-Meléndez et al., 2014). Similarly, proactivity, as a personal trait, has a positive link with entrepreneurial intentions (Usaci, 2015; Paul, \& Shrivatava, 2016). 


\section{The Theory of Planned Behavior and Entrepreneurial Intention}

According to Ajzen (1991) and Liñán and Chen (2009) the Theory of Planned Behavior (TPB) is based on three motivation factors that affect behaviour:

a) Attitude towards entrepreneurship (Personal Attitude) represents the personal opinion about how nice, good and useful it is to have your own company.

b) Subjective norm represents an assessment of the extent to which there is or is not social pressure from the environment to undertake a business venture.

c) Perceived behavioural control represents assessment of the degree of ability to start an entrepreneurial business, and later to run it successfully.

Within the extended Theory of Planned Behaviour (TPB), entrepreneurial intentions are seen as the effort that an individual will invest in performing an entrepreneurial activity (Paul, \& Shrivatava, 2016). In doing so, such attitudes towards entrepreneurship predict entrepreneurial intentions, and in turn entrepreneurial intentions predict planned entrepreneurial behaviour (Ajzen, 1991). TPB dimensions have a significant impact on entrepreneurial intentions (Roy, Akhtar, \& Das, 2017; Zhang, Wang, \& Owen, 2015; Moriano, Gorgievski, Laguna, Stephan, \& Zarafshani, 2012).

According to Fayolle and Liñán (2014) entrepreneurial intention is a characteristic that leads a person to open up his own company, start an entrepreneurial career and become self-employed. The study of entrepreneurial intentions provides a significant opportunity to understand and predict the ability for entrepreneurship (Rauch, \& Hulsink, 2015; Karimi, Biemans, Lans, Chizari, \& Mulder, 2016).

\section{Variables which Influence Entrepreneurial Intentions}

There are numerous research studies about the effects of various variables on the emergence of entrepreneurial intentions and entrepreneurship in general. Among other things, the effects of variables such as gender, the existence of an entrepreneurial tradition in the family, age and the possession of finance for starting a business are examined.

\section{Gender}

One of the most frequently studied topics in entrepreneurship is the impact of gender on the startup of an entrepreneurial venture and its success. According to the Global Entrepreneurship Monitor 2013, in 2012 more than 187 million out of 400 million entrepreneurs were women (Poggesi et al., 2016). The authors conclude that female entrepreneurship is a key component of the business sector worldwide. One group of studies deals with the comparison of women and men who are already entrepreneurs. According to (Jayawarna et al., 2015), there are many similarities between male and female entrepreneurs, which disperse the assumptions and prejudices about the shortcomings and weaknesses of women in the role of entrepreneurs.

The second group of studies deals with the examination of the entrepreneurial characteristics and intentions in both women and men. According to Santos et al. (2016), men and women share a similarity in entrepreneurial intentions, although they are somewhat more pronounced in men. In society, men are more encouraged to undertake entrepreneurial ventures, so women feel that entrepreneurship is not an acceptable career choice for them. Similarly, male students in Norway and Turkey show a much higher degree of entrepreneurial intentions than female students (Shneor et al., 2013). According to Diaz-Garcia and Jiménez-Moreno (2010) men put more thought into creating a company than determination to establish one. 
In doing so, there are no significant differences in entrepreneurial intentions for women and men. Recent research from different parts of the world also show similar tendencies: in Mexico men and women have similar levels of entrepreneurial intentions (Huezo-Poncen, \& Saiz-Álvarez, 2020), while in Greece (Vamvaka, Stoforos, Palaskas, \& Botsaris, 2020) and Vietnam (Nguyen, 2018), men still have slightly higher entrepreneurial intentions.

\section{Family Background}

The existence of a family background is also a significant topic in research into the impact on entrepreneurial intentions and entrepreneurship in general. These studies mostly confirm the positive relationship between these variables, for example (Jena, 2020; Herman, 2019; Palmer, Fasbender, Kraus, Birkner, \& Kailer, 2019; Sahinidis, Stavroulakis, Kossieri, \& Varelas, 2019). According to Kotlar and De Massis (2013) in family firms there are various goals, which is a consequence of the overlapping and interaction between family, ownership and business aspects. If a young person grows up in such an environment, one can assume that entrepreneurship and work in their own company is a natural phenomenon, and the entrepreneurial environment is thus a natural environment in which it will be easier to develop entrepreneurial intentions.

Similarly, a supportive family background increases the likelihood of someone starting an entrepreneurial venture (Jayawarna et al., 2014). Jain and Wajid Ali (2012) point out that those entrepreneurs who have a family business background show significantly more prominent features such as: achievement, innovativeness, locus of control and risk-taking. Also, according to Altinay et al. (2012) an existence of an entrepreneur in the family has an impact on the intentions to start a business venture.

\section{Age}

A somewhat smaller number of studies are directed on examining the impact of age on entrepreneurial intentions. According to Minola et al. (2016), self-employment motivation depends on age. In terms of both desirability and feasibility beliefs, motivation to open your own business reaches its peak in young years, experiencing a pronounced reduction towards late years. Similarly, Tsai et al. (2016) found that years of age have a negative impact on assessment of their own capabilities and entrepreneurial intention. A somewhat different result was obtained in the research (Jain, \& Wajid Ali, 2012), which states that younger entrepreneurs are more proactive than others, while entrepreneurs in their middle age have a stronger locus of control and high willingness to take risks than others. According to Nguyen (2018), age does not affect entrepreneurial intentions.

\section{Financial Opportunities}

The financial opportunities to start a new business can often affect entrepreneurial intentions. However, not much research has been dedicated to this topic. The reason for this may be that these surveys are mainly carried out in developed countries where the possession of money is not such a limiting factor due to the higher standard of living of potential entrepreneurs, and the better regulated financial incentives of the society. Perceived capability positively affects entrepreneurship intention (Tsai et al., 2016). Perceived capability Estimated capability may be partly understood as the possession of finance for launching entrepreneurial ventures, so it can be indirectly concluded that having finances affect entrepreneurial intentions. Pfeifer et al. (2016) showed that family wealth and family business exposure have a positive impact on the entrepreneurial intentions of Croatian students. 
The disposal of financial capital, in the general case, has a positive relationship with self-employment (Kim, Longest, \& Aldrich, 2013; Rodriguez, Tuggle, \& Hackett, 2009; Shinnar, \& Young, 2008). However, according to Sieger and Minola (2017), family financial support for an entrepreneurial venture can create some pressure on a potential entrepreneur and diminish his or her actual entrepreneurial intentions.

On the basis of the introductory and theoretical considerations, the six research questions were asked:

RQ1: Is there a statistically significant influence of the GEN - gender variable on the observed entrepreneurial dimensions?

RQ2: Is there a statistically significant impact of PAR - One of my parents has a private business variable on the observed entrepreneurial dimensions?

RQ3: Is there a statistically significant impact of YEA - The year in which the student is studying variable on the observed entrepreneurial dimensions?

RQ4: Is there a statistically significant impact of SUC - Student success in learning and studying variable on the observed entrepreneurial dimensions?

RQ5: Is there a statistically significant impact of FIN - The financial opportunities to start a new business variable on the observed entrepreneurial dimensions?

RQ6: Is there a moderating impact of GEN - gender variable in the relation between the influence of the variables of YEA - The year in which the student is studying, SUC - Student success in learning and studying and FIN - The financial opportunities to start a new business on the observed entrepreneurial dimensions?

\section{METHODOLOGY}

\section{Survey Instruments (Measures)}

Enterprise potential. The measurement of entrepreneurial potentials was carried out using a questionnaire based on the Attitude Toward Enterprise (ATE) test (Athayde, 2009). The questionnaire comprises 18 items (4 dimensions). The respondents evaluate the items on a seven-point Likert scale.

Individual entrepreneurial orientation. The measurement of individual entrepreneurial orientation was carried out using the Individual Entrepreneurial Orientation (IEO) questionnaire (Bolton, \& Lane 2012). The questionnaire comprises 10 items (3 dimensions). The respondents evaluate the items on a seven-point Likert scale.

The Theory of Planned Behaviour and entrepreneurial intention. The measurement of Theory of Planned Behaviour and entrepreneurial intentions dimensions was realized using the Entrepreneurial Intention Questionnaire (EIQ) (Liñán, \& Chen, 2009). The questionnaire comprises 20 items (4 dimensions). The respondents evaluate the items on a seven-point Likert scale.

\section{Participants}

The respondents were students in Serbia. This survey includes students from seven faculties of technical and economic orientation (University of Belgrade and University of Novi Sad). The sample consists of undergraduate and master's students, from the first to the fifth year of study, whereas this distribution is even. Students included in the research have no previous entrepreneurial experience. 
The survey was conducted through an anonymous questionnaire. The questionnaires were completed either during or after classes. A total of 700 questionnaires were distributed to students, 532 of which were returned.

A number of returned questionnaires were not completely filled in, so these questionnaires were removed. There were 44 such questionnaires. Thus, 488 questionnaires remained for statistical analysis and this number is the final scope of the research sample. The percentage of successfully returned and completed questionnaires by respondents is $69,7 \%$. The sample of 488 questionnaires obtained this way can be considered representative, both in qualitative and quantitative terms.

According to the observed variables, the sample has these characteristics:

- There were 337 (69.1\%) female students and 151 (30.9\%) male students in the sample.

- The age of the respondents ranges from 18 to 32, with the average age of the respondents being 21.38 (standard deviation 1,962).

- The research included undergraduate and master's students, from the first to the fifth year of study. There were 157 first-year students (32.17\%), 88 second-year students (18.03\%), 122 thirdyear students (25.00\%), 70 fourth-year students (14.34\%) and 51 fifth-year students (10.45\%).

- When considering the question (statement): I am an excellent and very successful student, 5 (1.02\%) students said they did not agree at all, 25 (5.12\%) students said they did not agree, 155 $(31,76 \%)$ of the students expressed a neutral attitude, 227 (46.52\%) of the students said to agree and $76(15.57 \%)$ of the students stated that they completely agreed.

- When considering the question (claim): One of my parents has their own private business, $106(21.7 \%)$ students said yes, while 382 (78.3\%) students said that their parents do not have a private business.

- When considering the question (statement): I have the necessary finances to open my own company, $213(43.65 \%)$ students said they did not agree at all, 102 (20.90\%) students said they did not agree, $81(16,60 \%)$ student expressed a neutral attitude, 76 (15.57\%) students agreed and $16(3.28 \%)$ students completely agreed with the statement.

\section{RESEARCH RESULTS}

For statistical data processing were used: t-tests, correlation and regression analysis and hierarchical regression analysis. The impact of the variables GEN - the respondents' gender and PAR - one of my parents has a private business on the observed entrepreneurial dimensions was assessed by means of t-tests because these are categorical variables. The impact of the variables YEA - the year in which the student is studying, SUC - student success in learning and studying and FIN - the financial opportunities to start a new business on the observed entrepreneurial dimensions was tested by correlation and regression analysis because these are continual variables. 


\section{Descriptive Statistics}

The descriptive statistics is shown in Table 1.

Table 1: Descriptive statistics.

\begin{tabular}{lccccccc}
\hline \multicolumn{1}{c}{ Dimensions and items } & Abbr. & N & Min & Max & Mean & $\begin{array}{c}\text { Deviation } \\
\text { Std. }\end{array}$ & $\alpha$ \\
\hline Leadership & LEA & 488 & 1 & 7 & 3.88 & $\mathbf{1 . 2 6 5}$ & .837 \\
\hline Creativity & CRE & 488 & 1 & 7 & 5.54 & $\mathbf{1 . 1 5 8}$ & .792 \\
\hline Achievement & ACH & 488 & 1 & 7 & 4.25 & $\mathbf{1 . 2 5 9}$ & .809 \\
\hline Personal control & PC & 488 & 1 & 7 & 4.11 & $\mathbf{1 . 2 0 5}$ & .702 \\
\hline Risk taking & RT & 488 & 1 & 7 & 4.16 & $\mathbf{1 . 3 3 5}$ & .777 \\
\hline $\begin{array}{l}\text { Innovativeness } \\
\text { Proactiveness }\end{array}$ & IN & 488 & 1 & 7 & 4.86 & $\mathbf{1 . 1 4 2}$ & .799 \\
\hline Personal attitude & PR & 488 & 1 & 7 & 4.98 & $\mathbf{1 . 2 1 7}$ & .786 \\
\hline Subjective norm & PA & 488 & 1 & 7 & 4.80 & $\mathbf{1 . 2 3 1}$ & .860 \\
\hline $\begin{array}{l}\text { Perceived behavioral control } \\
\text { Entrepreneurial intention }\end{array}$ & SN & 488 & 1 & 7 & 5.60 & $\mathbf{1 . 2 4 8}$ & .846 \\
\hline $\begin{array}{l}\text { Student success in learning } \\
\text { and studying }\end{array}$ & EI & 488 & 1 & 7 & 4.14 & $\mathbf{1 . 1 8 9}$ & .894 \\
\hline $\begin{array}{l}\text { Financial opportunities to } \\
\text { start a new business }\end{array}$ & SUC & 488 & 1.00 & 5.00 & 3.70 & $\mathbf{. 8 2 8}$ & \\
\hline
\end{tabular}

T-test analysis (examining the impact of variables GEN - Gender and PAR - One of my parents has a private business)

Table 2 shows the t-test analysis. This analysis shows whether the respondents of different gender, as well as those whose parents have a private business and those who do not, differ in relation to particular entrepreneurial dimensions. The bold values in Table 2 indicate the dimensions where there is a statistically significant difference in the average grades, relative to a particular categorical variable. 
RAJKOVIĆ. J., POŠTIN. J., KONJIKUŠIĆ. M., RUSIĆ. J. A., STOJKOVIĆ. H. S., NIKOLIĆ. M. § THE ENTERPRISE POTENTIAL, INDIVIDUAL ENTREPRENEURIAL ORIENTATION AND ENTREPRENEURIAL INTENTIONS OF STUDENTS IN SERBIA

Table 2: T-test of the average scores of the observed entrepreneurial dimensions for two categorical variables (GEN - Gender; PAR - One of my parents has a private business).

\begin{tabular}{|c|c|c|c|c|c|c|c|c|c|}
\hline \multirow{2}{*}{ Abbr. } & \multirow{2}{*}{$\begin{array}{l}\text { Mean } \\
\text { Total }\end{array}$} & \multicolumn{4}{|c|}{ GEN - The respondents' gender } & \multicolumn{4}{|c|}{$\begin{array}{c}\text { PAR - One of my parents has } \\
\text { a private business }\end{array}$} \\
\hline & & Male & Female & t-test & $\begin{array}{c}\text { Sig. } \\
\text { (2-tailed) }\end{array}$ & No & Yes & t-test & $\begin{array}{c}\text { Sig. } \\
\text { (2-tailed) }\end{array}$ \\
\hline LEA & 3.88 & 4.10 & 3.79 & 2.709 & .007 & 3.85 & 3.89 & -.307 & .759 \\
\hline CRE & 5.54 & 5.28 & 5.65 & -3.309 & .001 & 5.53 & 5.54 & -.093 & .926 \\
\hline $\mathrm{ACH}$ & 4.25 & 4.26 & 4.25 & .134 & .893 & 4.31 & 4.24 & .507 & .07 \\
\hline PC & 4.11 & 4.30 & 4.02 & 2.617 & .009 & 4.09 & 4.11 & -.252 & .801 \\
\hline RT & 4.16 & 4.27 & 4.12 & 1.248 & .158 & 4.20 & 4.15 & .349 & .727 \\
\hline IN & 4.86 & 4.82 & 4.88 & -.582 & .562 & 4.86 & 4.86 & .043 & .966 \\
\hline PR & 4.98 & 4.83 & 5.05 & -1.950 & .005 & 5.09 & 4.96 & 1.015 & .311 \\
\hline PA & 4.80 & 4.89 & 4.76 & 1.106 & .269 & 4.77 & 4.81 & -.252 & .801 \\
\hline SN & 5.60 & 5.38 & 5.69 & -2.466 & .014 & 5.70 & 5.57 & .986 & .325 \\
\hline $\mathrm{PBC}$ & 4.14 & 4.30 & 4.07 & 1.913 & .005 & 4.29 & 4.10 & 1.433 & .153 \\
\hline EI & 3.78 & 4.09 & 3.65 & 3.012 & .003 & 3.75 & 3.86 & -.654 & .513 \\
\hline
\end{tabular}

Correlation and regression analysis (examining the impact of variables YEA - The year in which the student is studying, SUC - Student success in learning and studying and FIN - The financial opportunities to start a new business)

The correlation coefficients between the continual variables YEA - the year in which the student is studying, SUC - student success in learning and studying, FIN - the financial opportunities to start a new business and the observed entrepreneurial dimensions are presented in Table 3. Pearson's correlation was used.

Table 3: Correlation coefficients.

\begin{tabular}{lccccccccccc}
\hline & LEA & CRE & ACH & PC & RT & IN & PR & PA & SN & PBC & EI \\
\hline $\begin{array}{l}\text { YEA - The year in } \\
\text { which the student is } \\
\text { studying }\end{array}$ & .022 & $-.094^{*}$ & -.019 & .047 & -.046 & -.038 & -.048 & .024 & -.018 & -.035 & -.077 \\
\hline $\begin{array}{l}\text { SUC - Student } \\
\text { success in learning } \\
\text { and studying }\end{array}$ & $.142^{* *}$ & $.137^{* *}$ & $.199^{* *}$ & $.098^{*}$ & .015 & .072 & $.184^{* *}$ & -.038 & $.100^{*}$ & .051 & -.033 \\
$\begin{array}{l}\text { FIN - Financial } \\
\text { opportunities to start } \\
\text { a new bus. }\end{array}$ & .086 & -.055 & .060 & .012 & $.141^{* *}$ & .069 & .058 & $.166^{* *}$ & .062 & $.274^{* *}$ & $.302^{* *}$ \\
\hline
\end{tabular}

${ }^{*} p<0.05 ; * * p<0.01$. 
The predictive effects of the variables YEA - the year in which the student is studying, SUC - student success in learning and studying, FIN - the financial opportunities to start a new business (independents) on the observed entrepreneurial dimensions (dependents) were determined by Multiple Regression Analysis. This results are given in Table 4 . Statistically significant values are given in bold font.

Table 4: Regression analysis.

\begin{tabular}{|c|c|c|c|c|c|c|}
\hline \multicolumn{7}{|c|}{ Independent variables } \\
\hline $\begin{array}{c}\text { Dependent } \\
\text { variables }\end{array}$ & $\begin{array}{l}\text { YEA - The } \\
\text { year in which } \\
\text { the student is } \\
\text { studying }\end{array}$ & $\begin{array}{l}\text { SUC - } \\
\text { Student } \\
\text { success in } \\
\text { learning and } \\
\text { studying }\end{array}$ & $\begin{array}{l}\text { FIN - Financial } \\
\text { opportunities } \\
\text { to start a new } \\
\text { bus. }\end{array}$ & $\mathrm{R}^{2}$ & $\mathrm{~F}$ & Sig. \\
\hline \multicolumn{7}{|c|}{$\beta$} \\
\hline LEA & .004 & $.140^{*}$ & .083 & .027 & 4.486 & .004 \\
\hline CRE & $-.114^{\star}$ & $.153^{\star *}$ & -.059 & .035 & 5.817 & .001 \\
\hline $\mathrm{ACH}$ & -.046 & $.203^{\star *}$ & .056 & .045 & 7.542 & .000 \\
\hline PC & .035 & $.093^{\star}$ & .010 & .011 & 1.789 & .148 \\
\hline $\mathrm{RT}$ & -.048 & .018 & $.141^{\star *}$ & .022 & 3.686 & .012 \\
\hline IN & -.048 & .077 & .067 & .012 & 1.956 & .120 \\
\hline PR & -.073 & $.192^{\star *}$ & .054 & .042 & 7.073 & .000 \\
\hline $\mathrm{PA}$ & .031 & -.046 & $.167^{\star *}$ & .030 & 5.040 & .002 \\
\hline $\mathrm{SN}$ & -.031 & $.103^{\star}$ & .060 & .015 & 2.378 & .069 \\
\hline $\mathrm{PBC}$ & -.041 & .050 & $.273^{\star *}$ & .079 & 13.769 & .000 \\
\hline EI & -.073 & -.031 & $.302^{* *}$ & .098 & 17.098 & .000 \\
\hline
\end{tabular}

\section{Gender as a Moderator}

The correlation analysis between the variables YEA - the year in which the student is studying, SUC - student success in learning and studying, FIN - the financial opportunities to start a new business and the observed entrepreneurial dimensions, for male and female students is presented in Table 5. In this table, the results confirming the moderating effect of gender are highlighted by bold font. Table 6 gives additional statistics only for couples in which the gender moderating effect was confirmed.

Table 5: Correlation coefficients.

\begin{tabular}{|c|c|c|c|c|c|c|c|c|c|c|c|c|}
\hline \multicolumn{2}{|c|}{$\begin{array}{l}\text { GEN - Gender } \\
\text { of the respondents }\end{array}$} & LEA & CRE & $\mathrm{ACH}$ & PC & RT & IN & PR & $\mathrm{PA}$ & SN & PBC & EI \\
\hline & YEA - Year & -.048 & -.104 & -.033 & -.053 & -.058 & -.046 & -.094 & .081 & -.128 & .014 & .038 \\
\hline \multirow[t]{3}{*}{ Male } & SUC - Success & $.113^{*}$ & $.103^{*}$ & $.183^{*}$ & .069 & .086 & $.209^{*}$ & $.150^{*}$ & .025 & .138 & .106 & .027 \\
\hline & FIN - Finance & -.005 & -.066 & .048 & -.024 & -.001 & -.010 & -.042 & -.029 & -.011 & $.162^{\star}$ & .119 \\
\hline & YEA - Year & .048 & -.095 & -.014 & .082 & -.044 & -.037 & -.030 & .000 & .025 & -.048 & $-.114^{*}$ \\
\hline \multirow[t]{2}{*}{ Fem. } & SUC - Success & $.199^{* *}$ & $.110^{*}$ & $.216^{* *}$ & $.150^{\star *}$ & .003 & .002 & $.178^{\star \star}$ & -.053 & .044 & .056 & -.017 \\
\hline & FIN - Finance & $.110^{*}$ & -.029 & .066 & .012 & $.201^{\star \star}$ & $.113^{*}$ & $.115^{\star}$ & $.259^{\star \star}$ & $.125^{*}$ & $.310^{* *}$ & $.365^{\star \star}$ \\
\hline
\end{tabular}


Table 6: Hierarchical regression analysis with GEN - gender as a moderator.

\begin{tabular}{|c|c|c|c|}
\hline Independent & Dependent & $\mathrm{R}$ square change & F-change \\
\hline $\begin{array}{l}\text { SUC - Student success in learning and } \\
\text { studying }\end{array}$ & IN & .009 & .263 \\
\hline \multirow{4}{*}{$\begin{array}{c}\text { FIN - Financial opportunities to start a } \\
\text { new business }\end{array}$} & PA & .018 & .689 \\
\hline & PBC & .008 & 5.448 \\
\hline & EI & .017 & 5.791 \\
\hline & RT & .009 & .227 \\
\hline
\end{tabular}

\section{DISCUSSION}

\section{Discussion of the Results of the Descriptive Statistics}

The results of the descriptive statistics (Table 1) show that from the observed entrepreneurial dimensions, the largest average scores are achieved for the dimensions $\mathrm{SN}$ - subjective norm and CRE - creativity. The high average score for SN - subjective norm is is in line with the national culture in Serbia (Vukonjanski et al., 2012), which is pronounced collectivist: promotes unity and solidarity, which, in this case, is manifested through increased human support in their surroundings.

The lowest average values were assigned to the EI - entrepreneurial intentions and LEA - leadership dimensions. Most of the other dimensions related to entrepreneurship have values around or above average. However, it is one thing to have certain characteristics, such as innovation and pro-activity and a positive attitude towards entrepreneurship, but it is quite another when it comes to firm entrepreneurial intentions. Simply, it is easier to sympathize with the business of an entrepreneur and have the desire to become an entrepreneur, rather than really having the strong desire and the will to achieve such a venture. Due to the low standard of living in Serbia, especially that of students, the very low average value for item FIN - the financial opportunities to start a new business comes as no surprise.

\section{Discussion of the Results of the t-test (Answering RQ1 and RQ2)}

The results of the t-test (Table 2) show that the variables GEN - the respondents' gender have a statistically significant influence on most of the observed entrepreneurial constructs. For men the more powerful dimensions are: LEA - leadership, PC - personal control, PBC - perceived behavioural control and EI - entrepreneurial intentions. The more pronounced dimensions for women are: CRE - creativity, $\mathrm{PR}$ - proactiveness and SN - subjective norm. There are no statistically significant differences in the dimensions: ACH - achievement, RT - risk taking, IN - innovativeness and PA - personal attitude. In this section, it can be concluded that men have more pronounced leadership qualities, as well as a greater desire and need for control, all of which leads to more pronounced entrepreneurial intentions. The result indicating that entrepreneurial intentions are more pronounced among male students. This is in agreement with most of the existing research, for example (Shneor et al., 2013; Antoncic et al., 2015; Leppel, 2016; Santos et al., 2016; Vamvaka, Stoforos, Palaskas, \& Botsaris, 2020; Nguyen, 2018). On the other hand, women are more creative and proactive, and they also have more support from their environment. Higher proactivity can be explained by being female students more conscientious. 
Greater support from the environment is probably not the result of more incentives for women to enter into entrepreneurship, but a higher level of confidence in girls in that period of life, and this is reflected in the result of greater proactivity, which indicates a higher degree of responsibility and conscientiousness. Knorr, Garzón and Martinez (2011) obtained a similar result regarding the need for achievement, according to which men and women have equal motivation to start their own business.

According to Table 2, the variable PAR - one of my parents has a private business does not show a statistically significant influence on any of the observed entrepreneurial constructs. This result is significantly different from most of the existing ones, indicating the positive impact of the existence of an entrepreneur in the family on entrepreneurial intentions and preferences for entrepreneurship (Jayawarna et al., 2014; Jain et al., 2012; Altinay et al., 2012; Jena, 2020; Herman, 2019; Palmer, Fasbender, Kraus, Birkner, \& Kailer, 2019; Sahinidis, Stavroulakis, Kossieri, \& Varelas, 2019). There is a similarity with research (Hatak, Harms, \& Fink, 2015; Nguyen, 2018), where it was shown that the entrepreneurial intentions of an individual are not influenced by having or not parents who are entrepreneurs. Such a uniform situation, in this paper, is apparently created because students whose parents do not have a private business also have similar entrepreneurial intentions. A possible explanation is that regardless of whether their parents have a private business, students see entrepreneurship as an opportunity and consider self-employment to be a great way to gain employment and a decent standard of living. It should be borne in mind that unfavourable circumstances (a relatively high unemployment rate and low standard of living) are strongly expressed in Serbia. The second question is to what extent entrepreneurial intentions are present. As shown by the descriptive statistics, they are still below average.

The answer to RQ1: the variable of GEN - gender has a statistically significant impact on the most of the observed entrepreneurial dimensions (LEA - leadership, CRE - creativity, PC - personal control, $\mathrm{PR}$ - proactiveness, $\mathrm{SN}$ - subjective norm, $\mathrm{PBC}$ - perceived behavioural control and EI - entrepreneurial intentions).

The answer to RQ2: the variable of PAR - One of my parents has a private business has virtually no statistically significant influence on the observed entrepreneurial dimensions.

\section{Discussion of the Correlation and Regression Analysis Results (Answering RQ3, RQ4 and RQ5)}

According to the correlation analysis (Table 3), the variable YEA - the year in which the student is studying has no statistically significant correlation, except with the CRE - creativity dimension. This correlation is negative. Younger students may overestimate their creativity and the importance of creativity for education, while older students view creativity-related issues more objectively. It should be noted that the correlation between the variable YEA - the year in which the student is studying and the dimension EI - entrepreneurial Intentions is negative, but not statistically significant. This points to the slightly negative impact of the year in which the student is studying on entrepreneurial intentions, where there is a slight drop in entrepreneurial intentions at the end of studies. At the end of their studies, students find it easier to find work within an existing company with their diploma. This result has a similarity with the results obtained in the research by Minola et al. (2016) and Tsai et al. (2016).

The variable SUC - student success in learning and studying produces statistically significant and positive correlations with all the dimensions of enterprise potential (LEA - leadership, CRE - creativity, $\mathrm{ACH}$ - achievement and PC - personal control), as well as with the dimensions PR - proactiveness and SN - subjective norm (Table 3). Therefore, student success in learning and studying develops and positively affects individual personality traits, which in this case are seen as entrepreneurial potentials and other dimensions related to entrepreneurship. 
However, the very existence of these potentials and traits contributes significantly to successful studying. Here, there seems to be a cyclical effect, where certain personality traits contribute to success in studies, and in turn this success serves to further enhance these same qualities.

Finally, support from the environment, and especially from family members becomes stronger thanks to success in studies. It is also interesting that SUC - student success in learning and studying has negative correlations with the constructs of PA - personal attitude and EI - entrepreneurial intentions. Although these correlations are not statistically significant, this result points to the direction of the influence of the variable SUC - student success in learning and studying. Successful students find good jobs more easily and will be able to live more effectively with their acquired professional knowledge and developed skills, so they are less likely to think about the risks and uncertainties of entrepreneurial ventures.

The variable FIN - the financial opportunities to start a new business realizes statistically significant and positive correlations with the following dimensions: RT - risk taking, PA - personal attitude, PBC - perceived behavioural control and EI - entrepreneurial intentions (Table 3). In doing so, the strongest correlation is achieved with the EI - entrepreneurial intentions dimension. This result is consistent with some existing research, for example (Kim, Longest, \& Aldrich, 2013; Rodriguez, Tuggle, \& Hackett, 2009; Shinnar, \& Young, 2008). It may thus be concluded that the possession of finance is the most influential variable for the existence of entrepreneurial intentions. The other correlations of this variable show that this is due to the fact that individuals who (relative/perceived) have significant financial resources also have an increased perception of their entrepreneurial abilities, a better opinion on entrepreneurship and are more willing to take risks (it is easier for them to take risks or risk is not perceived as strongly as it is by someone who does not have access to money). Practically, money helps in lifting of selfconfidence in entrepreneurial abilities and risk-taking possibilities. In addition, this result is largely the consequence of the current conditions in Serbia, which primarily refers to the low standard of living and the poor financial capabilities of most citizens. García-Rodríguez, Gil-Soto, Ruiz-Rosa and Mamour Sene (2015), also showed that desire has the greatest impact on entrepreneurial intentions in Spain (a representative of a highly developed country), while feasibility has the greatest impact on entrepreneurial intentions in Senegal (a representative of a less developed country). Serbia can be classified into the category of less developed countries, and the feasibility of engaging in entrepreneurial ventures is certainly linked to the possession of finance.

According to the regression analysis (Table 4), the corrected determination indexes $\mathrm{R} 2$ have quite low, but predominantly statistically significant values (0.011 to 0.098). The dimension EI - entrepreneurial intentions, followed by the dimension PBC - perceived behavioural control, are under the strongest predictive impact of the observed independent variables. The variable FIN - the possession of finance has the decisive influence on this result.

The results of regression analysis are consistent with the results of the correlation analysis. For example, according to both correlation and regression analysis, variables SUC - student success in learning and studying and FIN - the financial opportunities to start a new business have statistically significant impacts on completely different dimensions. Success in studies may develop entrepreneurial potentials dimensions (leadership, creativity, achievement, personal control) and proactivity, while the possession of finance develops the Theory of Planned Behaviour dimensions (personal attitude, perceived behavioural control), entrepreneurial intention and risk taking. 
The answer to RQ3: the variable of YEA - the year in which the student is studying has a statistically significant and negative impact on only one of the observed entrepreneurial dimensions (CRE - creativity).

The answer to RQ4: the variable of SUC - student success in learning and studying has a statistically significant and positive impact on the most of the observed entrepreneurial dimensions (LEA - leadership, CRE - creativity, ACH - achievement, PC - personal control, PR - proactiveness and SN - subjective norm).

The answer to RQ5: the variable of FIN - the financial opportunities to start a new business has a statistically significant and positive impact on some of the observed entrepreneurial dimensions (RT - risk taking, PA - personal attitude, PBC - perceived behavioural control and EI - entrepreneurial intentions).

\section{Discussion of the Moderating Effects of GEN - Gender (Answering RQ6)}

Tables 5 and 6 show relatively weak moderating influence of the variable GEN - gender on the relation between the variables YEA - the year in which the student is studying, SUC - student success in learning and studying and FIN - the financial opportunities to start a new business and the observed entrepreneurial dimensions. The statistically significant moderating impact occurs only in a small number of cases, which are concentrated around the variable FIN - the financial opportunities to start a new business. For women this variable has much more powerful and positive effects in several dimensions: RT - risk taking, PA - personal attitude, PBC - perceived behavioural control and EI - entrepreneurial intentions. Also, the variable SUC - student success in learning and studying has a more positive impact on certain dimensions for women: LEA - leadership, ACH - achievement, PC - personal control and PR - proactiveness. In these cases, the moderating effect of SUC - student success in learning and studying is not statistically significant, but the correlations in Table 5 indicate certain tendencies in this direction. Practically, the results of the correlation analysis increase for women. It is interesting that men showed a statistically significant increase in PBC - perceived behavioural control and EI entrepreneurial Intentions (T-test, Table 2).

The explanation for such results may lie in the fact that in cases of success in studying and the good financial opportunities, women are significantly more motivated and more determined, they know exactly what they want and how to use their professional and financial potentials. All this in turn leads to more positive attitudes towards entrepreneurship, greater self-confidence in assessing their own abilities, greater willingness to take risks, and, finally, stronger entrepreneurial intentions (especially in the case of having access to finance). Observed in the other direction, when women do not have the needed resources to start their own firm, they think much less about entrepreneurship. At the same time, men in such conditions still do not give up, and they continue to imagine their possible engagement in entrepreneurial work. It can be concluded that in terms of entrepreneurship women are more realistic and decisive, while men may prefer to be entrepreneurs, but they do not know how to go about achieving such a goal. This conclusion bears similarities with the result obtained by Diaz-Garcia and Jiménez-Moreno (2010), which suggests that, although men think more about setting up a company, they show less determination to do so.

The answer to RQ6: the moderating effect of the variable GEN - gender on the observed relations is not so strongly expressed, and acts in the way that for women the variables FIN - the financial opportunities to start a new business and SUC - student success in learning and studying are much more powerful and positively affect certain dimensions. 


\section{CONCLUSION}

The variable GEN - gender has a statistically significant effect on most of the observed dimensions. For men the most powerful dimensions are: LEA - leadership, PC - personal control, PBC - perceived behavioural control and EI - entrepreneurial intentions. The more pronounced dimensions for women are: CRE - creativity, PR - proactiveness and SN - subjective norm. The variable PAR - one of my parents has a private business does not show any statistically significant influence on any of the observed dimensions. The same holds true for the YEA - the year in which the student is studying variable, which has a statistically significant and negative impact only with the CRE - creativity dimension.

The variable SUC - student success in learning and studying generates statistically significant and positive impacts with all the entrepreneurial potential dimensions (LEA - leadership, CRE - creativity, $\mathrm{ACH}$ - achievement and PC - personal control), as well as with the dimensions of PR - proactiveness and $\mathrm{SN}$ - subjective norm. The variable FIN - the financial opportunities to start a new business realizes statistically significant and positive impacts predominantly with the dimensions of the Theory of Planned Behaviour dimensions (PA - personal attitude, PBC - perceived behavioural control) and with the dimensions of EI - entrepreneurial intentions and RT - risk taking. It should be noted that the variables SUC - student success in learning and studying and FIN - the financial opportunities to start a new business have statistically significant impacts on quite another entrepreneurial dimensions.

The influences of the observed variables on dimension of EI are of special importance - entrepreneurial intentions. The most important variable for entrepreneurial intentions is FIN - the financial opportunities to start a new business. Also, men have more pronounced entrepreneurial intentions. The other variables do not have a statistically significant impact on entrepreneurial intentions, but the tendency is for entrepreneurial intentions to decline in cases where parents do not have a private business, then in the final years of study and in situations where there is significant success in studies. Under such conditions, students are more inclined to focus on their careers in existing companies.

The moderating effect of the variable GEN - gender is as follows: in the case of successful studying and the possession of finance, women are more motivated and more determined, have more positive attitudes towards entrepreneurship, highly assess their own abilities, are more ready to take risks and have stronger entrepreneurial intentions (especially in the case of the possession of finance). When women do not have the money to start their own businesses, then they think much less about entrepreneurship. Overall, men may prefer more to be entrepreneurs, but women approach entrepreneurship more realistically and decisively.

The findings in this paper are based on a sample of students in Serbia. This statement is a basic limitation of the study. However, the findings may be particularly suitable for understanding similar relationships in other transitional and less developed countries. In practical terms, the research has shown that the intensification of entrepreneurial intentions among young people in Serbia may be achieved through education and assistance from state institutions. The help of state institutions should be logistical and advisory, but it is particularly important to provide appropriate financial support to potential entrepreneurs who have good ideas, but not the funds to start an entrepreneurial venture. In addition, stronger support and more attention should be paid to groups with reduced entrepreneurial intentions, namely female students and successful students in the final years of study. 
A special contribution of this paper in the theoretical sense is that the effects of The year in which the student is studying and Student success in learning and studying on the observed entrepreneurial dimensions are examined, as these are two variables that have not been sufficiently researched in this context so far, despite numerous published papers in the field of entrepreneurial intentions. The contribution of this paper in the practical sense is visible in the consideration of the way all five observed variables influence on entrepreneurial dimensions, which resulted in appropriate proposals for encouraging entrepreneurial intentions among students in Serbia.

\section{REFERENCES}

Ajzen, I. (1991). Theory of Planned Behavior. Organizational Behavior and Human Decision Processes, 50(2), 179-211.

Altinay, L., Madanoglu, M., Daniele, R. \& Lashley, C. (2012). The influence of family tradition and psychological traits on entrepreneurial intention. International Journal of Hospitality Management, 31(2), 489-499.

Antoncic, B., Bratkovic, T., Singh, G. \& DeNoble, A.F. (2015). The Big Five Personality-Entrepreneurship Relationship: Evidence from Slovenia. Journal of Small Business Management, 53(3), 819-841.

Athayde, R. (2009). Measuring Enterprise Potential in Young People. Entrepreneurship Theory and Practice, 33(2), 481-500.

Bolton, D.L. \& Lane, M.D. (2012). Individual Entrepreneurial Orientation: development of a measurement instrument. Education + Training, 54(2/3), 219-233.

Brandstätter, H. (2011). Personality aspects of entrepreneurship: A look at five meta-analyses. Personality and Individual Differences, 51(3), 222-230.

Caliendo, M., Fossen, M. \& Kritikos, A.S. (2014). Personality characteristics and the decisions to become and stay self-employed. Small Business Economics, 42(4), 787-814.

Çolakoğlu, N. \& Gözükara, I. (2016). A comparison study on personality traits based on the attitudes of university students toward entrepreneurship. 5 $^{\text {th }}$ International Conference on Leadership, Technology, Innovation and Business Management, Procedia - Social and Behavioral Sciences, 229, 133-140.

Coulibaly, S.K., Erbao, C. \& Mekongcho, T.M. (2018). Economic globalization, entrepreneurship, and development. Technological Forecasting and Social Change, 127(C), 271-280.

Delanoë-Gueguen, S. \& Fayolle A. (2018). Crossing the Entrepreneurial Rubicon: A Longitudinal Investigation. Journal of Small Business Management, 57(3), 1044-1065.

Delanoë-Gueguen, S. \& Liñán, F. (2018). A longitudinal analysis of the influence of career motivations on entrepreneurial intention and action. Canadian Journal of Administrative Sciences / Revue Canadienne des Sciences de l'Administration, 36(4), 527-543.

Diaz-Garcia, M.C. \& Jiménez-Moreno, J. (2010). Entrepreneurial intention: The role of gender. International Entrepreneurship and Management Journal, 6(3), 261-283.

Donaldson, C. (2019). Intentions resurrected: a systematic review of entrepreneurial intention research from 2014 to 2018 and future research agenda. International Entrepreneurship and Management Journal, 15(3), 953-975.

Fayolle, A. \& Liñán, F. (2014). The future of research on entrepreneurial intentions. Journal of Business Research, 67(5), 663-666.

Fellnhofer, K. \& Kraus, S. (2015). Examining attitudes towards entrepreneurship education: A comparative analysis among experts. International Journal of Entrepreneurial Venturing, 7(4), 396-411.

García-Rodríguez, F.J., Gil-Soto, E., Ruiz-Rosa, I. \& Mamour Sene, P. (2015). Entrepreneurial intentions in diverse development contexts. a cross-cultural comparison between Senegal and Spain. International Entrepreneurship Management Journal, 11(3), 511-527. 
RAJKOVIĆ. J., POŠTIN. J., KONJIKUŠIĆ. M., RUSIĆ. J. A., STOJKOVIĆ. H. S., NIKOLIĆ. M. § THE ENTERPRISE POTENTIAL, INDIVIDUAL ENTREPRENEURIAL

Hatak, I., Harms, R. \&Fink, M. (2015). Age, job identification, and entrepreneurial intention. Journal of Managerial Psychology, 30(1), 38-53.

Herman, E. (2019). Entrepreneurial Intention among Engineering Students and Its Main Determinants. Procedia Manufacturing, 32, 318-324.

Huezo-Ponce L. \& Saiz-Álvarez J.M. (2020). Education, Gender, and Entrepreneurial Intention: The Case of Mexico. In: Leitão J., Nunes A., Pereira D., Ramadani V. (eds) Intrapreneurship and Sustainable Human Capital. Studies on Entrepreneurship, Structural Change and Industrial Dynamics. (Cham: Springer), 137-154.

Jain, R. \& Wajid Ali, S. (2012). Personal Characteristics of Indian Entrepreneurs and Intrapreneurs An Empirical Study. Management and Labour Studies, 37(4), 295-322.

Jayawarna, D., Jones, O. \& Marlow, S. (2015). The influence of gender upon social networks and bootstrapping behaviours. Scandinavian Journal of Management, 31(3), 316-329.

Jayawarna, D., Jones, O. \& Macpherson, A. (2014). Entrepreneurial potential: The role of human and cultural capitals. International Small Business Journal, 32(8), 918-943.

Jena, R.K. (2020). Measuring the impact of business management Student's attitude towards entrepreneurship education on entrepreneurial intention: A case study. Computers in Human Behavior, 107, 106275.

Karabulut, A.T. (2016). Personality Traits on Entrepreneurial Intention., Procedia - Social and Behavioral Sciences, $229,12-21$.

Karimi, S., Biemans, H.J.A., Lans, T., Chizari, M. \&Mulder, M. (2016). The Impact of Entrepreneurship Education: A Study of Iranian Students' Entrepreneurial Intentions and Opportunity Identification. Journal of Small Business Management, 54(1), 187-209.

Kim, P.H., Longest, K.C. \& Aldrich, H.E. (2013). Can You Lend Me a Hand? Task-Role Alignment of Social Support for Aspiring Business Owners. Work and Occupations, 40(3), 213-249.

Knorr, H., Garzón, D. \& Martínez, D. (2011). Motivations and differences upon reconciling professional and personal life: an empirical study of businesswomen and businessmen in Valencian Community. International Entrepreneurship Management Journal, 7(3), 391-412.

Koe, W.L. (2016). The relationship between Individual Entrepreneurial Orientation (IEO) and entrepreneurial intention. Journal of Global Entrepreneurship Research, 6, 13.

Kotlar, J. \& De Massis, A. (2013). Goal Setting in Family Firms: Goal Diversity, Social Interactions, and Collective Commitment to Family-Centered Goals. Entrepreneurship Theory and Practice, 37(6), 1263-1288.

Leppel, K. (2016). The incidence of self-employment by sexual orientation. Small Business Economics, 46(3), 347-363.

Liñán, F. \& Chen, Y.W. (2009). Development and Cross-Cultural Application of a Specific Instrument to Measure Entrepreneurial Intention. Entrepreneurship Theory and Practice, 33(3), 593-617.

Mahfud, T., Triyono, M.B., Sudira, P. \& Mulyani, Y. (2020). The influence of social capital and entrepreneurial attitude orientation on entrepreneurial intentions: the mediating role of psychological capital. European Research on Management and Business Economics, 26(1), 33-39.

Miller, D. (1983). The correlates of entrepreneurship in three types of firms. Management Science, 29(7), 770-91.

Minola, T., Criaco, G. \& Obschonka, M. (2016). Age, culture, and self-employment motivation. Small Business Economics, 46(2), 187-213.

Moriano, J.A., Gorgievski, M., Laguna, M., Stephan, U., Zarafshani, K. (2012). A Cross-Cultural Approach to Understanding Entrepreneurial Intention. Journal of Career Development, 39(2), 162-185.

Mortan, R.A., Ripoll, P., Carvalho, C. \& Bernal, M.C. (2014). Effects of emotional intelligence on entrepreneurial intention and self-efficacy. Journal of Work and Organizational Psychology, 30(3), 97-104.

Mueller, S.L. \& Thomas, A.S. (2001). Culture and Entrepreneurial Potential: A Nine Country Study of Locus of Control and Innovativeness. Journal of Business Venturing, 16(1), 51-75. 
Muñoz-Bullón, F., Sánchez-Bueno, M.J. \& Vos-Saz, A. (2015). Nascent entrepreneurs' personality attributes and the international dimension of new ventures. International Entrepreneurship and Management Journal, 11(3), 473-492.

Mwasalwiba, E.S. (2010). Entrepreneurship education: A review of its objectives, teaching methods, and impact indicators. IEEE Engineering Management Review, 40(2), 72-94.

Nguyen, C. (2018). Demographic factors, family background and prior self-employment on entrepreneurial intention - Vietnamese business students are different: why? Journal of Global Entrepreneurship Research, $8(10), 1-17$.

Nowiński, W. \& Haddoud, M.Y. (2019). The role of inspiring role models in enhancing entrepreneurial intention. Journal of Business Research, 96, 183-193.

Padilla-Meléndez, A., Fernández-Gámez, M.A. \& Molina-Gómez, J. (2014), Feeling the risks: effects of the development of emotional competences with outdoor training on the entrepreneurial intent of university students. International Entrepreneurship and Management Journal, 10(4), 861-884.

Palmer, C., Fasbender, U., Kraus, S., Birkner, S. \& Kailer, N. (2019). A chip off the old block? The role of dominance and parental entrepreneurship for entrepreneurial intention. Review of Managerial Science,, 15(2), 287-307. DOI:10.1007/s11846-019-00342-7.

Paul, J. \& Shrivatava, A. (2016). Do young managers in a developing country have stronger entrepreneurial intentions? Theory and debate. International Business Review, 25(6), 1197-1210.

Pfeifer, S., Šarlija, N. \& Zekić Sušac, M. (2016). Shaping the Entrepreneurial Mindset: Entrepreneurial Intentions of Business Students in Croatia. Journal of Small Business Management, 54(1), 102-117.

Poggesi, S., Mari, M. \& De Vita, L. (2016). What's new in female entrepreneurship research? Answers from the literature. International Entrepreneurship and Management Journal, 12(3), 735-764.

Rauch, A. \& Hulsink, W. (2015). Putting Entrepreneurship Education Where the Intention to Act Lies: An Investigation Into the Impact of Entrepreneurship Education on Entrepreneurial Behavior. Academy of Management Learning \& Education, 14(2), 187-204.

Reijonen, H., Hirvonen, S., Nagy, G., Laukkanen, T. \& Gabrielsson, M. (2015). The impact of entrepreneurial orientation on B2B branding and business growth in emerging markets. Industrial Marketing Management, $51,35-46$.

Robinson, S. \& Stubberud, H.A. (2014). Elements of entrepreneurial orientation and their relationship to entrepreneurial intent. Journal of Entrepreneurship Education, 17(2), 1-11.

Rodriguez, P., Tuggle, C.S. \& Hackett, S.M. (2009). An Exploratory Study of How Potential "Family and Household Capital” Impacts New Venture Start-up Rates. Family Business Review, 22(3), 259-272.

Roy, R., Akhtar, F. \& Das, N. (2017). Entrepreneurial intention among science \& technology students in India: extending the theory of planned behavior. International Entrepreneurship and Management Journal, 13(4), 1013-1041.

Sahinidis A., Stavroulakis D., Kossieri E. \& Varelas S. (2019). Entrepreneurial Intention Determinants Among Female Students. The Influence of Role Models, Parents' Occupation and Perceived Behavioral Control on Forming the Desire to Become a Business Owner. In: Kavoura A., Kefallonitis E., Giovanis A. (eds) Strategic Innovative Marketing and Tourism. Springer Proceedings in Business and Economics. (Cham: Springer), 173-178.

Samo, A.H. \& Huda, N.U. (2019). Triple Helix and academic entrepreneurial intention: understanding motivating factors for academic spin-off among young researchers. Journal of Global Entrepreneurship Research, 9(12), 1-15.

Santos, F.J., Roomi, M.A. \& Liñán, F. (2016). About Gender Differences and the Social Environment in the Development of Entrepreneurial Intentions. Journal of Small Business Management, 54(1), 49-66.

Shinnar, R.S. \& Young, C.A. (2008). Hispanic immigrant entrepreneurs in the Las Vegas metropolitan area. Motivations for entry into and outcomes of self-employment. Journal of Small Business Management, $46(2), 242-262$. 
Shneor, R., Camgöz, S.M. \& Karapinar, P.B. (2013). The interaction between culture and sex in the formation of entrepreneurial intentions. Entrepreneurship \& Regional Development An International Journal, 25(9-10),781-803.

Sieger, P. \& Minola, T. (2017). The Family's Financial Support as a "Poisoned Gift". A Family Embeddedness Perspective on Entrepreneurial Intentions. Journal of Small Business Management, 55(S1), 179-204.

Tsai, K.H., Chang H.C. \& Peng, C.Y. (2016). Refining the linkage between perceived capability and entrepreneurial intention: roles of perceived opportunity, fear of failure, and gender. International Entrepreneurship and Management Journal, 12(4), 1127-1145.

Usaci, D. (2015). Predictors of Professional Entrepreneurial Intention and Behavior in the Educational Field. Procedia - Social and Behavioral Sciences, 187, 178-183.

Vamvaka, V., Stoforos, C., Palaskas, T. \& Botsaris, C. (2020). Attitude toward entrepreneurship, perceived behavioral control, and entrepreneurial intention: dimensionality, structural relationships, and gender differences. Journal of Innovation and Entrepreneurship, 9(5), 1-26.

Vukonjanski, J., Nikolić, M., Hadžić, O., Terek, E. \&Nedeljković, M. (2012). Relationship between GLOBE organizational culture dimensions, job satisfaction and leader-member exchange in Serbian organizations. Journal for East European Management Studies, 17(3), 333-368.

Zhang, P., Wang, D.D. \& Owen, C.L. (2015). A Study of Entrepreneurial Intention of University Students. Entrepreneurship Research Journal, 5(1), 61-82. 


\section{PREDUZETNIČKI POTENCIJAL, INDIVIDUALNA PREDUZETNIČKA ORIJENTACIJA I PREDUZETNIČKE NAMERE STUDENATA U SRBIJI}

\section{Rezime:}

U ovom radu dati su rezultati istraživanja učenika o uticajima pet varijabli na dimenzije potencijala preduzeća, individualnu preduzetničku orijentaciju, teoriju planiranog ponašanja (TPB) i dimenziju preduzetničke namere studenata. Uočeni su uticaji sledećih varijabli: Pol, Jedan od mojih roditelja ima privatno preduzeće, Godina u kojoj student studira, Uspeh studenata u učenju i Finansijske mogućnosti za započinjanje novog posla. Ispitanici studiraju na sedam fakulteta u Srbiji. Uzorak je obuhvatio 488 ispitanika. Najuticajnija varijabla na dimenziju preduzetničke namere su finansijske mogućnosti za započinjanje novog posla. Takođe, muškarci imaju izraženije preduzetničke namere. Uspeh u studijama pozitivno utiče na preduzetničke potencijale i proaktivnost, dok posedovanje finansija pozitivno utiče na preduzetničke namere i spremnost na rizik. U slučajevima uspešnih studija i posedovanja finansija, žene su više motivisane, odlučnije i imaju izraženije preduzetničke namere (posebno u slučaju da imaju finansijska sredstva). Iako muškarci možda više žele da postanu preduzetnici, žene preduzetništvu pristupaju realnije i odlučnije.

\section{Ključne reči:}

preduzetnički potencijal, individualna preduzetnička orijentacija, preduzetničke namere, studenti, Srbija.

\section{Klasifikacija jela:}

L26, D23 